\title{
Speak up to save science
}

\section{Budget crises are forcing many countries to make unprecedented spending cuts. Scientists must engage with their governments to protect funding for science.}

$\mathbf{T}$ he current world financial crisis has caused some governments to drastically cut back on science funding. For example, last year, the Italian government announced a $19 \%$ drop in funding, and the Spanish government initiated a $15 \%$ cut. Alarmingly, the science budgets in both countries are continuing their downward trajectory this year. Researchers around the globe need to fight pending cuts and make sure that politicians see science as an essential investment, not a discretionary expense.

Take the recent example of the UK. British politicians were undertaking a comprehensive spending review to address a large national budget deficit this year and, in the process, were threatening to cut science funding by up to $15 \%$. But researchers took action to persuade their elected representatives of the importance of science as a driver of the economy (Nat. Med. $14,1129,2008)$.

Jennifer Rohn, a University College London cell biologist, launched a campaign called Science is Vital. In collaboration with the Campaign for Science and Engineering in the UK, the campaign collected 35,000 signatures on a petition-presented to Downing Street on 14 October-stating that science funding was necessary to keep the UK economy competitive in the global landscape. Moreover, the group held a rally at the Treasury with 2,000 people in attendance on 9 October and arranged for 100 scientists to meet their representatives in Parliament on 12 October.

Encouragingly, their voices were heard: although the government's new budget, announced on 20 October, was indeed slashed by $19 \%$, the budget for scientific research was not touched (but science funding in the UK is still expected to drop by $10 \%$ by 2015 when adjusted for inflation). Although it is unclear exactly how much the campaign influenced the government's decision to back down on science funding cuts, at the very least the participants were able to get the public's attention.

In the US, Republicans have just taken over leadership of the House of Representatives. Pledge to America, the Republican Party platform, calls for across-the-board cuts for nonmilitary spending to 2008 levels. According to the American Association for the Advancement of Science, this would take more than $\$ 3$ billion out of the pockets of agencies that fund science. Researchers in the US must now speak out to ensure that this does not happen.
And there are many ways to do so. Scientists-from students to department heads-can and should get involved, particularly when there is a change in leadership that could affect science funding drastically. On an individual basis, scientists can write letters to their representatives and to local newspapers. However, the Science is Vital campaign shows that working in large groups can be more effective at getting the attention of both elected officials and the general public. Along these lines, Euroscience, the European Association for the Promotion of Science and Technology, which represents researchers across Europe, has been lobbying the EU and individual European governments to maintain current funding levels.

On a more local level, universities should encourageand provide forums for-professors and students alike to get involved in political discourse about science, particularly when the government is threatening to cut science funding. Scientific societies and foundations could also provide leadership in organizing petitions, rallies and meetings between researchers and government officials. The collaboration of science organizations with patient advocacy groups may be another effective way of getting the attention of politicians.

To be sure, some scientists are already quite politically active and have the ear of elected officials. However, if strength is in numbers, it is clear that not enough scientists are taking time away from the bench to connect with their governments.

Admittedly, even when scientists do take the time to protest budget cuts, politicians still may not listen. After the cuts of 15\% were announced in Spain last year, Spanish scientists organized a protest in Madrid, and 51 prominent biologists wrote an open letter to the government objecting to these cuts, which was backed by the Confederation of Spanish Scientific Societies, on behalf of 30,000 Spanish researchers. In spite of these actions, the science budget in Spain will still drop by an additional 8\% this year.

Especially in tough economic times, scientists must realize that they cannot depend on others to fight budget cuts and argue for the value of their research. If scientists shirk this responsibility and instead stick to their lab benches, they cannot claim to have fought for their funding when it disappears in the next round of budget cuts. 